\title{
PRESERVED CYTOPLASM IN CHARRED AGATHOXYLON-TYPE WOOD FROM THE PERMIAN OF BRAZILIAN PARANÁ BASIN
}

\author{
ISABELA DEGANI-SCHMIDT, MARGOT GUERRA-SOMMER \& TAÍS FREITAS \\ Instituto de Geociências, UFRGS, Cx.P. 15001, Av. Bento Gonçalves, 9500, 91501-970, Porto Alegre, RS, Brazil. \\ degani.schmidt@ufrgs.br; margot.sommer@ufrgs.br; tais.freitas@ufrgs.br
}

\begin{abstract}
The present study documents cytoplasm preserved by charring in parenchymatous cells of the wood rays of secondary xylem tissue in Agathoxylon-type wood from the Permian of the Brazilian Paraná Basin. Charred logs and bark fragments were collected from the upper coal seam of Sakmarian age (U-Pb dating 291 $\pm 1.3 \mathrm{Ma}$ ) in the Faxinal Coalfield, Rio Grande do Sul, Brazil (Rio Bonito Formation, southern Paraná Basin). The material was examined under field emission gun - scanning electron microscopy. Results of energy dispersive spectroscopy are compatible with organic matter. Three types of cell contents preserved in parenchymatous tissue were observed in the charred samples: solidified, hydrolyzed and agglutinated. Lightning strikes are hypothesized as the likely fossilizing agent for plant cytoplasm, acting as killer and fixer and thus preventing the natural decay that ensues from plant death in the natural environment. The persistence of charcoalified plant tissues has been frequently documented since Paleozoic times, whereas preservation of cytoplasm is less common in wildfire settings since it likely involves a particular interaction of paleobotanic, cytological, physiological, taphonomic and paleoenvironmental factors. Nevertheless, preserved cytoplasm is probably ubiquitous in the fossil record and underreported.
\end{abstract}

Keywords: charcoal, paleowildfires, late Paleozoic, Gondwana.

RESUMO - O presente estudo documenta a ocorrência de citoplasma preservado por queima em células parenquimáticas no raio do xilema secundário em lenho tipo Agathoxylon do Permiano da Bacia do Paraná brasileira. Troncos e fragmentos de córtex queimados foram coletados da camada superior de carvão do Sakmariano (291土1.3Ma por datação U-Pb) na Mina do Faxinal, Rio Grande do Sul, Brasil (Formação Rio Bonito, sul da Bacia do Paraná). O material foi examinado sob microscopia eletrônica de varredura - canhão de emissão de campo. Resultados de espectroscopia por energia dispersiva são compatíveis com matéria orgânica. Três tipos de conteúdo celular preservado em tecido parenquimático foram observados no material queimado: solidificado, hidrolisado e aglutinado. Descargas elétricas atmosféricas seriam o provável agente fossilizador do citoplasma vegetal, com atuação aniquiladora e fixadora, evitando, assim, a degradação natural que sucede à morte da planta no ambiente natural. A persistência de tecidos vegetais queimados tem sido frequentemente documentada desde o Paleozoico, enquanto que a preservação de citoplasma é menos comum em cenários de incêndios, já que provavelmente envolve uma interação particular entre fatores paleobotânicos, citológicos, fisiológicos, tafonômicos e paleoambientais. Não obstante, a preservação de citoplasma é provavelmente onipresente no registro fóssil e pouco documentada.

Palavras-chave: carvão vegetal, paleoincêndios, Neopaleozoico, Gondwana.

\section{INTRODUCTION}

The global prevalence of wildfire events during the Permian has been related with high levels of paleoatmospheric oxygen based on the equivalence between inertinite and charcoal (Scott, 2000, 2010; Diessel, 2010; Glasspool et al., 2015). Under such conditions, even vegetation with high-moisture contents becomes more susceptible to ignition by increased frequency of lightning strikes (Glasspool et al., 2015).

The occurrence of abundant charcoalified plant remains is reported as wildfire evidence in peat-forming environments from several localities of Gondwana during the Permian. Environments frequently disturbed by wildfires emerged from the studies carried out by Jasper et al. $(2008,2013,2016)$ and Slater et al. (2015) for both western and eastern Gondwana.
In the southern Brazilian Paraná Basin, the presence of charcoal is likewise ubiquitous during the Permian (Jasper et al., 2011a,b; Manfroi et al., 2012, 2015). In the Faxinal Coalfield, subject of the present study, DeganiSchmidt et al. (2015) described an extensive accumulation of autochthonous-parautochthonous charcoalified bark fragments and logs in the top coal seam and concluded that recurrent, low-temperature wildfires were common and systemic events in the peatland.

The process of charring can be considered as 'instant fossilization', with insignificant chemical and morphological changes once burial of the charred remains takes place (Rowe \& Jones, 2000). Charring provides rigidity and resistance to the plant tissue and prevents the fossils from collapsing during diagenesis, turning them into a permanent record within the 
strata. However, charring also adds to the fragility of the fossils reducing the preservation likelihood following significant transport prior to deposition (Wang, 2004; Friis et al., 2006). Under autochthonous-parautochthonous conditions, the charring of plant organs allows the preservation of not only hard tissues like wood, but also of soft organs like flowers (e.g. Friis \& Skarby, 1981).

Degani-Schmidt \& Guerra-Sommer (2016a) described secondary phloem associated with the secondary xylem of Agathoxylon-type wood in an assemblage of charcoalified logs and bark fragments from the Faxinal Coalfield. The occurrence of such delicate tissue fulfilled several preservation conditions such as probable desiccation before burning, autochthonous, low-temperature wildfires and parautochthonous deposition of the remains.

Fossilization of physiologically active plant tissue is supposedly a rather infrequent event, nevertheless there are reports of cytoplasm, organelles, and even DNA from material preserved since Precambrian times (e.g. Taylor \& Millay, 1977; Brack-Hanes \& Vaughn, 1978; Niklas, 1982; Edwards \& Axe, 2004; Schoenhut et al., 2004; Koller et al., 2005; Ozerov et al., 2006; Bomfleur et al., 2014). Wang (2004, 2006, 2007) and Wang et al. (2008) focused especially on the analysis of cytoplasm preserved by charring through lightning and wildfires.

The present study documents putative cytoplasm preserved by charring in parenchymatous tissue of Agathoxylon-type wood from the Permian of the Brazilian Paraná Basin, and discusses the finding under the light of the existent anatomical, taphonomic, paleobotanical and paleoenvironmental data.

\section{GEOLOGIC AND PALEONTOLOGICAL CONTEXT}

The study area comprises the Faxinal Coalfield, in the southeastern outcrop belt of the Rio Bonito Formation in the Brazilian Paraná Basin, Rio Grande do Sul State (Figure 1). The Rio Bonito Formation is included in a second order Carboniferous-Early Triassic sequence (Gondwana I Supersequence according to Milani et al., 2007). These strata are related to a paralic setting, i.e., adjacent to estuarine, deltaic, backshore, foreshore, and shoreface siliciclastic depositional environments (Holz et al., 2010). Extensive peat swamps developed under cool temperate conditions at a paleolatitude of approximately $50^{\circ} \mathrm{S}$ during the Permian (Rees et al., 2002).

A $10 \mathrm{~cm}$ thick fossiliferous tonstein layer is interbedded in the top coal seam $\mathrm{S}$ and was dated at $291 \pm 1.3 \mathrm{Ma}$ (radiometric age after Simas et al., 2012), corresponding to the late Sakmarian (Cohen et al., 2013 updated 2017). The tonstein occurs continuously throughout the coalfield ( $c a .1 .6$ $\mathrm{km}^{2}$ ) and contains abundant plant organ compressions of the Glossopteris Flora. In depth stratigraphic, petrographic and paleobotanical information is given by Degani-Schmidt et al. (2015) and Degani-Schmidt \& Guerra-Sommer (2016b).

Previous analysis of the large autochthonoushypautochthonous charcoalified logs included in the lower and upper coal boundaries with the tonstein considered that recurrent wildfires were predominantly ignited by lightning strikes and controlled by variations in the water table (Degani-Schmidt et al., 2015). Volcanic events cannot be excluded as ignition source for wildfires in this peat-forming environment (Jasper et al., 2011a). However, geochemical analysis indicated that the ash-fall layer (tonstein) was deposited at a cool temperature on the peat surface (Simas et al., 2013).

\section{MATERIAL AND METHODS}

The compressed specimens of Agathoxylon-type wood come from the coal attached to the lower and upper surfaces of the tonstein layer interbedded in the top coal seam (DeganiSchmidt \& Guerra-Sommer, 2016a). Large-sized specimens (up to $21.8 \times 13.4 \mathrm{~cm}$ ) could have only been obtained because they were adhered to the highly silicified tonstein rock, which held the specimens together. The outer thin layer (bark) and the adjacent youngest secondary xylem of the compressed logs are charred and identified as inertinite, while the internal xylem is coalified and corresponds to vitrinite (DeganiSchmidt et al., 2015). The samples were previously identified as charcoal (Degani-Schmidt et al., 2015; Degani-Schmidt \& Guerra-Sommer, 2016a) according to the criteria established by Scott (2010) and come from the charred bark and youngest xylem from the periphery of the logs.

The secondary xylem is composed of tracheids and uniseriate parenchymatous rays. Tracheids are uniseriate with generally isolated pitting, biseriate with sub-opposite to alternate pitting and triseriate with opposite to sub-opposite pitting. Tangential views show uniseriate parenchymatous rays 1-11 cells high (Degani-Schmidt \& Guerra-Sommer, 2016a).

Small fragments were sampled with the aid of dissecting needles, mounted on standard stubs with double-sided tape, gold coated, and subsequently examined and photographed with an Inspect F50 FEI field emission gun scanning electron microscope (FEG-SEM). The chemical composition of cell walls and contents was analyzed using energy dispersive spectroscopy (EDS) according to Wang et al. (2007). However, since the macroscopic charcoal was included in coal and considering its extremely soft and brittle nature, the samples were not chemically cleansed with acids ( $\mathrm{HCl}, \mathrm{HF})$.

Ten stubs have been analyzed from a total of seven specimens. The material is deposited at the Paleobotanical Collection of the Universidade Federal do Rio Grande do Sul (UFRGS), Brazil under the numbers Pb4587A, Pb4587B, $\mathrm{Pb} 4618, \mathrm{~Pb} 4626 \mathrm{~A}, \mathrm{~Pb} 5122 \mathrm{~A}, \mathrm{~Pb} 5126, \mathrm{~Pb} 5128$.

Sample codes followed by letters $(\mathbf{A} / \mathbf{B})$ correspond respectively to the coal under and overlying a single tonstein slab. Stubs received the specimen code followed by a twodigit number.

Plates were composed with Adobe Photoshop CS6. Transformations made to the images consist of cropping, rotation, contrast and brightness adjustments. 


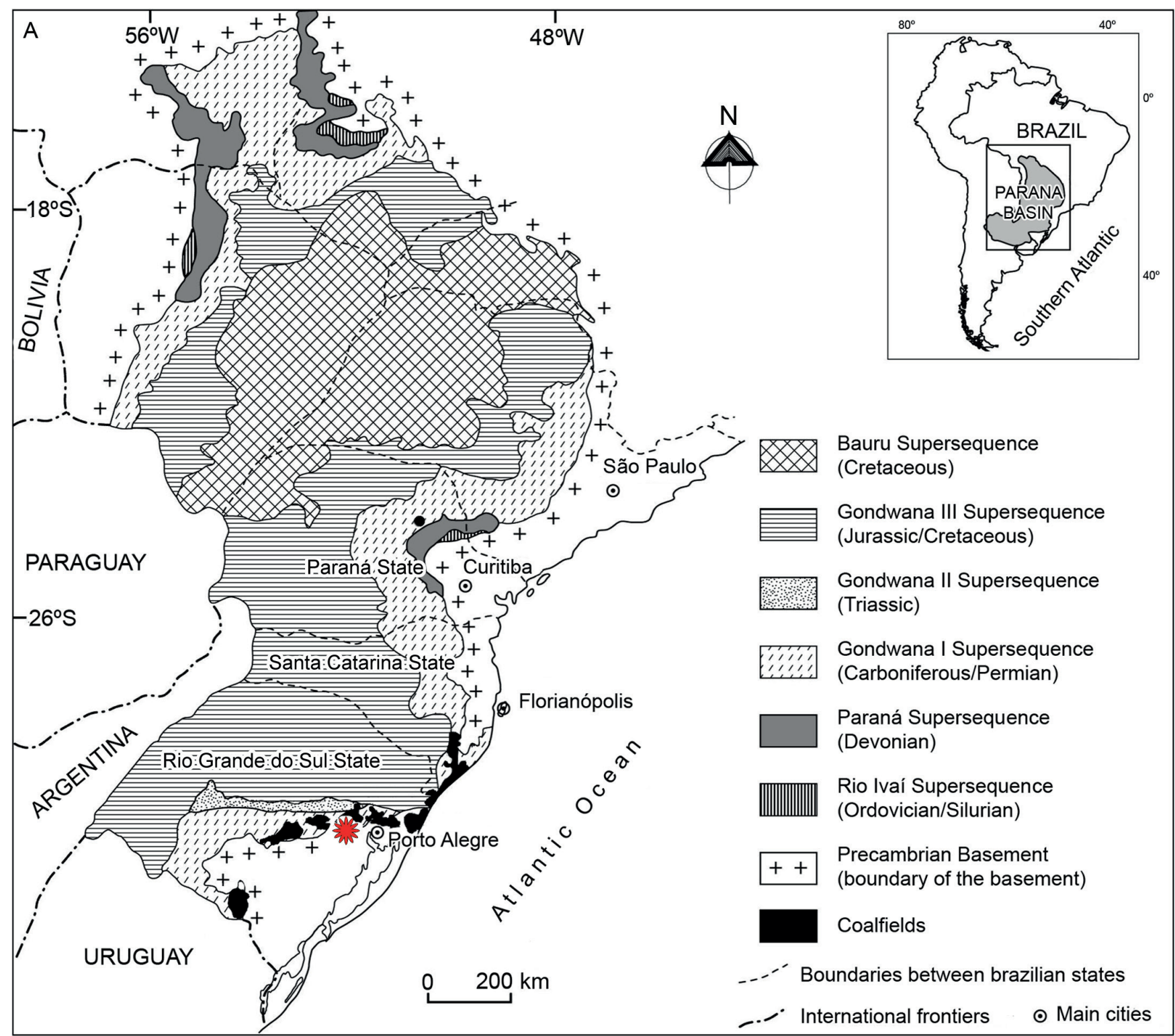

Figure 1. Location map of the Faxinal Coalfield, and stratigraphic framework of the Brazilian Paraná Basin (modified from Degani-Schmidt \& GuerraSommer, 2016b).

\section{RESULTS}

The EDS measurements (Figure 2, Table 1, supplementary material) allowed distinguishing between organic and mineral matter. The highest Si levels (above 10\%) occur in crystalshaped particles. There is a dominance of $\mathrm{C}$ (above 30\%) followed by O $(3.91-10.53 \%)$ in the organic matter. As a general trend, cell contents have no or very low levels of $\mathrm{O}$ (below 5\%) in comparison to cell walls (above 5\%). The presence of the trace elements $\mathrm{Au}, \mathrm{Rb}, \mathrm{Ge}$ and $\mathrm{Rn}$ is attributed to the gold coating of the material and is thus not considered in the analysis.

Cells with contents occur exclusively in the parenchymatous rays of secondary xylem. Three types of cell contents were observed: solidified (Figures 3A, B), hydrolyzed (Figures 3C, D) and agglutinated (Figure 3E), which are defined as follows.
The solidified type is massive and has a vesiculated appearance (Figure 3B). Vesicles are mostly isodiametric circular and triangular but can also be kidney-shaped/ ellipsoid. The shape of the solidified content is similar to the cell cavity but smaller in size, appearing to be shrunken in relation to it. The hydrolyzed cell content presents filamentous/granular remains (Figures 3C, D). The agglutinated remains have appearance of clumped debris and, unlike the other two types, feature high content of mineral matter (Figure 3E).

In some areas of the same specimen that featured the solidified cell content, corrugated cell walls were observed in the tracheids of the secondary xylem. The corrugation is present in both inner and outer surfaces of the tracheid walls (Figure 3H). 

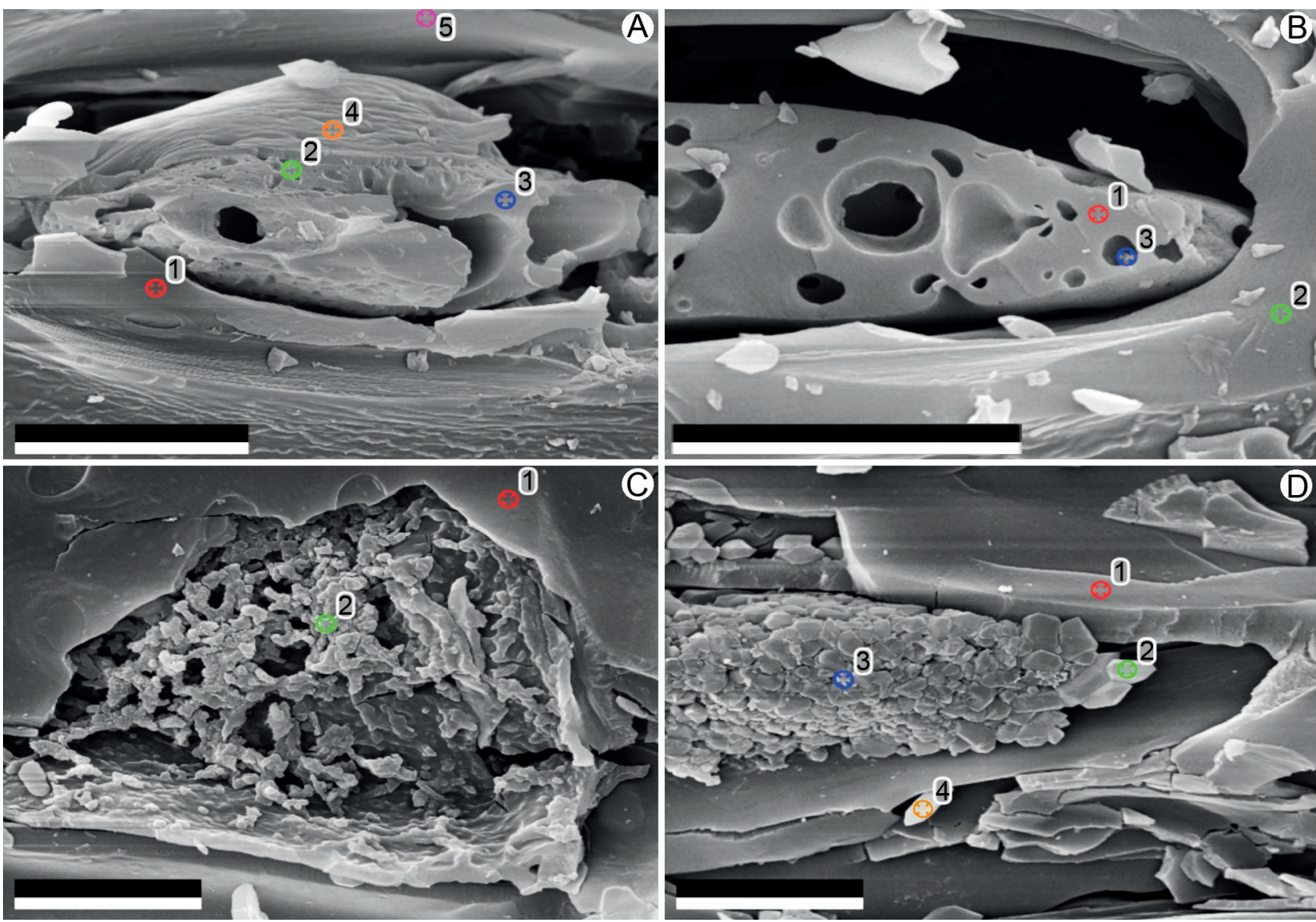

Figure 2. EDS measurement spots in cell walls and contents. A, Pb5128-54 area 1; B, Pb5128-54 area 2; C, Pb4618-16 area 1; D, Pb4618-16 area 2. The numbers within the photos correspond to those in Table 1. Scale bars $=5 \mu \mathrm{m}$.

Table 1. Elemental composition of the charred plant tissues by weight $\%$ from the EDS measurement spots on samples A-D shown in Figure 2 (see also supplementary material). Abbreviations: $\mathrm{W}$, cell wall; $\mathrm{C}$, cell content; $\mathrm{M}$, mineral particle.

\begin{tabular}{|c|c|c|c|c|c|c|c|c|c|c|c|c|c|c|}
\hline Measured spot & W & $\mathrm{C}$ & W & W & W & $\mathrm{C}$ & W & $\mathrm{C}$ & W & $\mathrm{C}$ & W & $\mathrm{M}$ & $\mathrm{C}$ & M \\
\hline Element & $\mathrm{A} 1$ & $\mathrm{~A} 2$ & A3 & A4 & A5 & B1 & B2 & B3 & $\mathrm{C} 1$ & $\mathrm{C} 2$ & D1 & D2 & D3 & D4 \\
\hline $\mathrm{C}$ & 47.24 & 48.75 & 46.83 & 51.48 & 60.92 & 48.96 & 34.99 & 41.75 & 64.19 & 55.97 & 51.63 & 22.64 & 11.32 & 27.59 \\
\hline $\mathrm{O}$ & 5.52 & & & & 6.37 & 4.31 & 6.52 & 4.04 & 11.27 & 3.91 & 10.53 & 22.03 & 10.49 & 10.70 \\
\hline $\mathrm{Si}$ & & & & 4.18 & & & & 3.21 & & & 1.96 & $15.63^{*}$ & $20.64 *$ & $11.17^{*}$ \\
\hline $\mathrm{Sr}$ & & & & & & & & & & & & 7.06 & & 4.92 \\
\hline $\mathrm{Rb}$ & & & & & & 1.10 & 1.61 & & 0.99 & 0.84 & & & 1.91 & \\
\hline $\mathrm{Tc}$ & & & & & & & 1.03 & & 0.61 & & 0.70 & 0.34 & & 0.34 \\
\hline $\mathrm{Rn}$ & & & & & & 0.17 & & 0.01 & 0.11 & 0.13 & & 0.12 & & \\
\hline $\mathrm{Au}$ & 47.24 & 51.09 & 53.11 & 43.82 & 32.71 & 37.98 & 45.16 & 50.99 & 19.08 & 23.29 & 35.13 & 25.80 & 55.21 & 36.77 \\
\hline $\mathrm{Ge}$ & & & & & & 7.48 & & & 3.75 & 4.74 & & 6.37 & & 8.42 \\
\hline $\mathrm{Mn}$ & & 0.16 & 0.07 & & & & 9.03 & & & & 0.06 & & & \\
\hline $\mathrm{Ra}$ & & & & & & & & & & & & & 0.41 & 0.09 \\
\hline \multicolumn{15}{|l|}{$\mathrm{Pd}$} \\
\hline $\mathrm{Al}$ & & & & 0.52 & & & & & & & & & & \\
\hline $\mathrm{Na}$ & & & & & & & 1.65 & & & & & & & \\
\hline
\end{tabular}

*Highest Si content 


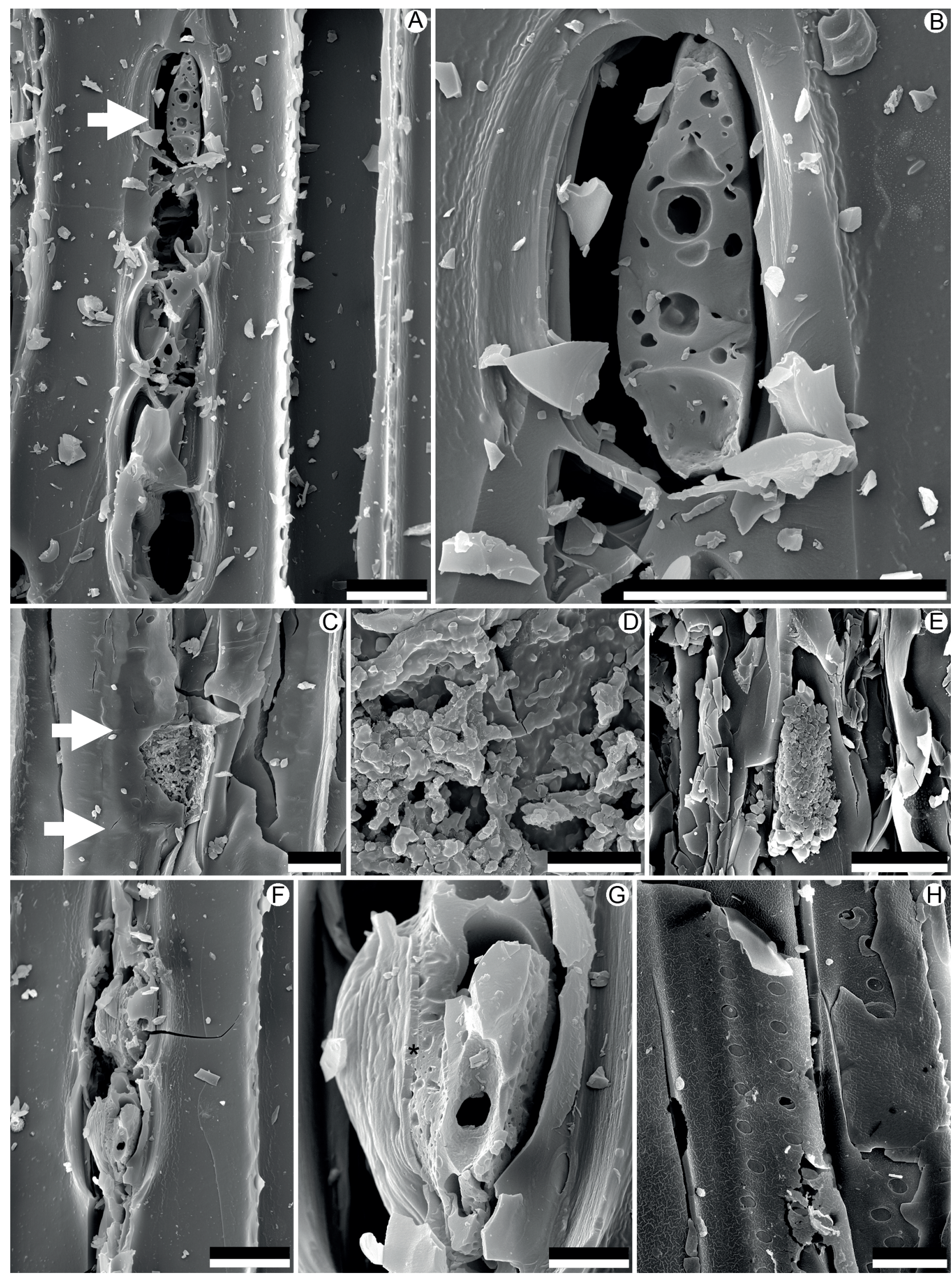

Figure 3. Appearance of cell contents and cell walls. A, parenchymatous ray in tangential view with associated solidified cell content (arrow; Pb5128-54). B, detail of (A). C, cross field (arrows) in radial view showing ripped cell wall of probable parenchyma cell with hydrolyzed cellular content ( $\mathrm{Pb} 4618-16)$. D, detail of (C). E, agglutinated remains (Pb4618-16). F, like (A) (Pb5128-54). G, detail of (F) showing * cell wall adhered to the cell content. H, corrugated tracheid walls (Pb5128-54). Scale bars: A-C, E-F, H $=20 \mu \mathrm{m} ; \mathrm{D}, \mathrm{G}=5 \mu \mathrm{m}$. 


\section{DISCUSSION}

EDS measurements yielded results that agree with the pattern of $\mathrm{O} / \mathrm{C}$ ratios described by Brodowski et al. (2005) for black carbon in soils. Oxygen contents in organic remains tend to increase from interior (cell content) to exterior surfaces (cell walls) since lignin, cellulose and wood retain more $\mathrm{O}$. The low $\mathrm{O} / \mathrm{C}$ ratio is indicative of incomplete combustion (charcoalification) of the organic matter. Areas with higher $\mathrm{Si}$ content (mineral matter) had higher O levels (Table 1: D2-D4).

The higher levels of $\mathrm{C}$ obtained for the solidified and hydrolyzed masses confer greater probability that they have been preserved "in situ" inside the plant cell. On the other hand, the occurrence of crystal-shaped particles high in $\mathrm{Si}$ in the agglutinated masses (Figure 2D) suggests that they are composed of mineral matter. Consequently, the agglutinated remains could correspond to debris contamination inside the cell lumina.

The scarcity of material featuring preserved cytoplasm among the samples analyzed here agrees with the estimation by Wang (2007) that preservation of cytoplasm only occurs in less than $3 \%$ of charcoalified mesofossils. This reflects the need of very specific circumstances for preservation.

According to Hather (2000), during wildfire the soft tissue either deteriorates or solidifies, leaving a formless mass of glass charred tissue. Nevertheless, good preservation occurs if it has been slowly dried prior to charring.

However, Wang $(2004,2007)$ observed that lightning strikes allow for good cytoplasm preservation in specific areas of the wood tissues. Wang (2004) proposed lightning as the likely fossilizing agent for plant cytoplasm, acting as killer and fixer preventing the natural decay that ensues plant death in the natural environment. While lightning directly affects only one tree, the lightning current has a killing radius of up to $10 \mathrm{~m}$. The electromagnetic current spreads over the plant surfaces and through the cambium. Therefore, the affected cells are the physiologically active ones from the youngest secondary xylem and phloem (Wang, 2004 and references therein).

Distinct forms of cytoplasm preservation like solidification and hydrolysis are determined by the position of the cell in relation to the cambium and whether it was affected by the electrical discharge (Wang, 2004). The cytoplasm solidification (baking according to Wang, 2007; Figures 3A, B) would be prompted by the lightning current, while the hydrolysis (Figures 3C, D) is the natural path of cytoplasm degradation after the plant death (Wang, 2004 and references therein). The agglutination of remains clumped with silica crystals (Figure 2E) might occur randomly.

Comparisons between the contents of experimentally charred tissues and preserved features seen in Devonian fossils indicated that the cells in the fossils were alive at the time of fossilization (Edwards \& Axe, 2004). In the present material, likewise, there is no evidence of plasmolysis, and the solidified cytoplasm remains are smooth and appear to be from active cells, instantly baked by high temperature.

In the permineralized cytoplasm of pteridophyte gametophytes of Pennsylvanian age, Taylor \& Millay (1977) observed large vesicles with irregular shapes and concluded that they reflected the original physical state of the cell cytoplasm rather than effect of diagenesis.

In controlled experiments with heat and fire, Wang (2007) observed that the distance between flame and plant tissue plays a role in preservation. Only tissues about $1 \mathrm{~mm}$ away from the flame have their cytoplasm preserved, including organelles and vacuoles.

In charring experiments with flowers, Lupia (1995) showed that tissue shrinkage varies in different structures, with different temperatures and duration. There seems to be some shrinkage of the solidified Agathoxylon cytoplasm in relation to the cell lumen considering the gap between them (Figures 3B, G), corroborating the inferences by Degani-Schmidt et al. (2015) and Degani-Schmidt \& Guerra-Sommer (2016a) of low-temperature fires, which were probably of short duration as well. The environmental desiccation was likely not severe, just enough to allow the plants to burn superficially, considering that the inner wood is coalified rather than charred (Degani-Schmidt et al., 2015).

The presence of the masses exclusively inside the parenchymatous cells of the wood rays in the xylem tissue in specimens that also contain secondary phloem (Degani-Schmidt \& Guerra-Sommer, 2016a) indicates that the preservation of the cytoplasm took place in the physiologically active cells close to the cambium, and that the event that preserved the cytoplasm was likely the same event that killed the plant.

The occurrence of the three types of preserved cell contents possibly reflects a preservation gradient inside the xylem. The cytoplasm closest to the cambium could have been baked/solidified by the electromagnetic current of a lightning strike, the hydrolyzed content represents the natural fate of the cytoplasm upon plant death, and the agglutinated material probably represents mineral debris as shown by the EDS measurements. The wall corrugation could have been caused by a closer proximity of these cells to the flames.

The solidified remains occur in the same specimen as the corrugated walls, thus reinforcing the "baked" origin of the wall corrugation. The hydrolyzed and the agglutinated remains occur in other specimens.

Preservation of organic matter mostly results from selective preservation of resistant biomolecules (Gupta et al., 2007), but charcoalification is a remarkable exception to this general rule since it can preserve both hard and soft tissues equally. The possibility of a resiniferous origin for the cell contents is not considered because they only occur in the cells of the parenchymatous rays. Considering the data presented here, it seems plausible that wildfires ignited by lightning strikes were responsible for the preservation of physiologically active tissue like secondary phloem, previously described for this material by Degani-Schmidt \& Guerra-Sommer (2016a), and cytoplasm of parenchyma ray cells.

The identification of fossil cytoplasm presented here fulfilled the criteria established by Wang (2007) and Wang et al. (2010), namely (i) three-dimensional preservation; (ii) its organic composition can be visually recognized in contrast to crystal-faceted particles; (iii) results of EDS measurements are compatible with organic matter; (iv) the cell contents have a coherent relationship with the lumen; (v) the contents 
are heterogenous (i.e. feature cavities) very similar to living cells; (vi) the shapes of the structured cavities are similar to actual organelles; (vii) the deep burial of the fossils precludes contamination from younger/extant material.

\section{CONCLUSIONS}

The Early Permian peat-forming swamp forest preserved in the Faxinal Coalfield in the southern Brazilian Paraná Basin was subjected to particular environmental and taphonomic circumstances. They allowed for the preservation of cytoplasm in the parenchymatous rays of the secondary xylem of charred logs of Agathoxylon-type wood.

Considering the data presented here, it seems plausible that wildfires ignited by lightning strikes were responsible for the preservation of physiologically active tissue like secondary phloem and cytoplasm. The preservation of cytoplasm specifically in parenchymatous cells close to the cambium supports this hypothesis.

\section{ACKNOWLEDGMENTS}

I.D.S. (PDJ 152791/2016-7) and M.G.S. wish to thank the Brazilian National Council of Technological and Scientific Development CNPq for the research grants. The authors are grateful to two anonymous reviewers whose input greatly helped to improve the manuscript.

\section{REFERENCES}

Bomfleur, B.; McLoughlin, S. \& Vajda, V. 2014. Fossilized nuclei and chromosomes reveal 180 million years of genomic stasis in royal ferns. Science, 343:1376-1377. doi:10.1126/science.1249884

Brack-Hanes, S.D. \& Vaughn, J.C. 1978. Evidence of Paleozoic chromosomes from lycopod microgametophytes. Science, 200:1383-1385. doi:10.1126/science.200.4348.1383

Brodowski, S.; Amelung, W.; Haumaier, L.; Abetz, C. \& Zech, W. 2005. Morphological and chemical properties of black carbon in physical soil fractions as revealed by scanning electron microscopy and energy-dispersive X-ray spectroscopy. Geoderma, 128:116-129. doi:10.1016/j.geoderma.2004.12.019

Cohen, K.M.; Finney, S.C.; Gibbard, P.L. \& Fan, J.X. 2013. The ICS international chronostratigraphic chart. Episodes, 36:199-204.

Degani-Schmidt, I. \& Guerra-Sommer, M. 2016a. Charcoalified Agathoxylon-type wood with preserved secondary phloem from the lower Permian of the Brazilian Parana Basin. Review of Palaeobotany and Palynology, 226:20-29. doi:10.1016/j. revpalbo.2015.12.003

Degani-Schmidt, I. \& Guerra-Sommer, M. 2016b. Epidermal morphology and ecological significance of Glossopteris pubescens nom. nov. from the Brazilian Permian (Sakmarian). Review of Palaeobotany and Palynology, 232:119-139. doi:10.1016/j.revpalbo.2016.06.002

Degani-Schmidt, I.; Guerra-Sommer, M.; Oliveira Mendonça, J.; Mendonça Filho, J.G.; Jasper, A.; Cazzulo-Klepzig, M. \& Iannuzzi, R. 2015. Charcoalified logs as evidence of hypautochthonous/autochthonous wildfire events in a peatforming environment from the Permian of southern Paraná Basin (Brazil). International Journal of Coal Geology, 146:55-67. doi:10.1016/j.coal.2015.05.002
Diessel, C.F. 2010. The stratigraphic distribution of inertinite. International Journal of Coal Geology, 81:251-268. doi:10.1016/j.coal.2009.04.004

Edwards, D. \& Axe, L. 2004. Anatomical evidence in the detection of the earliest wildfires. Palaios, 19:113-128. doi:10.1669/08831351(2004)019<0113:AEITDO > 2.0.CO;2

Friis, E.M.; Pedersen, K.R. \& Crane, P.R. 2006. Cretaceous angiosperm flowers: innovation and evolution in plant reproduction. Palaeogeography, Palaeoclimatology, Palaeoecology, 232:251-293. doi:10.1016/j.palaeo.2005.07.006

Friis, E.M. \& Skarby, A. 1981. Structurally preserved angiosperm flowers from the Upper Cretaceous of southern Sweden. Nature, 291:484-486. doi:10.1038/291484a0

Glasspool, I.J.; Scott, A.C.; Waltham, D.; Pronina, N. \& Shao, L. 2015. The impact of fire on the Late Paleozoic Earth system. Frontiers in Plant Science, 6:756. doi:10.3389/fpls.2015.00756

Gupta, N.S.; Briggs, D.E.; Collinson, M.E.; Evershed, R.P.; Michels, R.; Jack, K.S. \& Pancost, R.D. 2007. Evidence for the in situ polymerisation of labile aliphatic organic compounds during the preservation of fossil leaves: implications for organic matter preservation. Organic Geochemistry, 38:499-522. doi:10.1016/j. orggeochem.2006.06.011

Hather, J.G. 2000. Archaeological parenchyma. Londres, Archetype, $97 \mathrm{p}$.

Holz, M.; França, A.B.; Souza, P.A.; Iannuzzi, R. \& Rohn, R. 2010. A stratigraphic chart of the Late Carboniferous/Permian succession of the eastern border of the Paraná Basin, Brazil, South America. Journal of South American Earth Sciences, 29:381-399. doi:10.1016/j.jsames.2009.04.004

Jasper, A.; Agnihotri, D.; Tewari, R.; Spiekermann, R.; Pires, E.F.; Da Rosa, A.A.S. \& Uhl, D. 2016. Fires in the mire: repeated fire events in Early Permian 'peat forming' vegetation of India. Geological Journal, 52:955-969. doi:10.1002/gj.2860

Jasper, A.; Guerra-Sommer, M.; Abu-Hamad, A.M.; Bamford, M.; Bernardes-de-Oliveira, M.E.C.; Tewari, R. \& Uhl, D. 2013. The burning of Gondwana: Permian fires on the southern continent - a palaeobotanical approach. Gondwana Research, 24:148-160. doi:10.1016/j.gr.2012.08.017

Jasper, A.; Uhl, D.; Guerra-Sommer, M.; Abu-Hamad, A.M. \& Machado, N.T.G. 2011a. Charcoal remains from a tonstein layer in the Faxinal Coalfield, Lower Permian, southern Paraná Basin, Brazil. Anais da Academia Brasileira de Ciências, 83:471-481. doi:10.1590/S0001-37652011000200009

Jasper, A.; Uhl, D.; Guerra-Sommer, M.; Bernardes-de-Oliveira, M.E.C. \& Machado, N.T.G. 2011b. Upper Paleozoic charcoal remains from South America: multiple evidences of fire events in the coal bearing strata of the Paraná Basin, Brazil. Palaeogeography, Palaeoclimatology, Palaeoecology, 306:205218. doi:10.1016/j.palaeo.2011.04.022

Jasper, A.; Uhl, D.; Guerra-Sommer, M. \& Mosbrugger, V. 2008. Palaeobotanical evidence of wildfires in the Late Palaeozoic of South America - Early Permian, Rio Bonito Formation, Paraná Basin, Rio Grande do Sul, Brazil. Journal of South American Earth Sciences, 26:435-444. doi:10.1016/j.jsames.2008.08.002

Koller, B.; Schmitt, J.M. \& Tischendorf, G. 2005. Cellular fine structures and histochemical reactions in the tissue of a cypress twig preserved in Baltic amber. Proceedings of the Royal Society of London B: Biological Sciences, 272:121-126. doi:10.1098/ rspb.2004.2939

Lupia, R. 1995. Paleobotanical data from fossil charcoal: an actualistic study of seed plant reproductive structures. Palaios, 10:465-477. doi:10.2307/3515048

Manfroi, J.; Jasper, A.; Guerra-Sommer, M. \& Uhl, D. 2012. Subarborescent lycophytes in coal-bearing strata from the Artinskian 
(early Permian/Cisuralian) of the Santa Catarina coalfield (Paraná Basin, SC, Brazil). Revista Brasileira de Paleontologia, 15:135-140. doi:10.4072/rbp.2012.2.02

Manfroi, J.; Uhl, D.; Guerra-Sommer, M.; Francischini, H.; Martinelli, A.G.; Soares, M.B. \& Jasper, A. 2015. Extending the database of Permian palaeo-wildfire on Gondwana: charcoal remains from the Rio do Rasto Formation (Paraná Basin), Middle Permian, Rio Grande do Sul State, Brazil. Palaeogeography, Palaeoclimatology, Palaeoecology, 436:77-84. doi:10.1016/j. palaeo.2015.07.003

Milani, E.J.; Melo, J.H.G.; Souza, P.A.; Fernandes, L.A. \& França, A.B. 2007. Bacia do Paraná. Boletim de Geociências da Petrobras, 15:265-287.

Niklas, K.J. 1982. Differential preservation of protoplasm in fossil angiosperm leaf tissues. American Journal of Botany, 69:325334. doi:10.1002/j.1537-2197.1982.tb13264.x

Ozerov, I.A.; Zhinkina, N.A.; Efimov, A.M.; Machs, E.M. \& Rodionov, A.V. 2006. Feulgen-positive staining of the cell nuclei in fossilized leaf and fruit tissues of the Lower Eocene Myrtaceae. Botanical Journal of the Linnean Society, 150:315321. doi:10.1111/j.1095-8339.2006.00471.x

Rees, P.M.; Ziegler, A.M.; Gibbs, M.T.; Kutzbach, J.E.; Behling, P.J. \& Rowley, D.B. 2002. Permian phytogeographic patterns and climate data/model comparisons. The Journal of Geology, 110:1-31. doi:10.1086/324203

Rowe, N.P. \& Jones, T.P. 2000. Devonian charcoal. Palaeogeography, Palaeoclimatology, Palaeoecology, 164:331-338. doi:10.1016/ S0031-0182(00)00191-7

Schoenhut, K.; Vann, D.R. \& LePage, B.A. 2004. Cytological and ultrastructural preservation in Eocene Metasequoia leaves from the Canadian High Arctic. American Journal of Botany, 91:816-824. doi:10.3732/ajb.91.6.816

Scott,A.C. 2000. The Pre-Quaternary history of fire. Palaeogeography, Palaeoclimatology, Palaeoecology, 164:281-329. doi:10.1016/ S0031-0182(00)00192-9

Scott, A.C. 2010. Charcoal recognition, taphonomy and uses in palaeoenvironmental analysis. Palaeogeography, Palaeoclimatology, Palaeoecology, 291:11-39. doi:10.1016/j. palaeo.2009.12.012

Simas, M.W.; Guerra-Sommer, M.; Cazzulo-Klepzig, M.; Menegat, R.; Santos, J.O.S.; Ferreira, J.A.F.\& Degani-Schmidt, I. 2012.Geochronological correlation of the main coal interval in Brazilian Lower Permian: radiometric dating of tonstein and calibration of biostratigraphic framework. Journal of South American Earth Sciences, 39:1-15. doi:10.1016/j. jsames.2012.06.001

Simas, M.W.; Guerra-Sommer, M.; Mendonça Filho, J.G.; CazzuloKlepzig, M.; Formoso, M.L.L. \& Degani-Schmidt, I. 2013. An accurate record of volcanic ash fall deposition as characterized by dispersed organic matter in a lower Permian tonstein layer (Faxinal Coalfield, Paraná Basin, Brazil). Geologica Acta, 11:45-57. doi:10.1344/105.000001835

Slater, B.J.; McLoughlin, S. \& Hilton, J. 2015. A high-latitude Gondwanan lagerstätte: the Permian permineralised peat biota of the Prince Charles Mountains, Antarctica. Gondwana Research, 27:1446-1473. doi:10.1016/j.gr.2014.01.004

Taylor, T.N. \& Millay, M.A. 1977. Structurally preserved fossil cell contents. Transactions of the American Microscopical Society, 96:390-393. doi:10.2307/3225870

Wang, X. 2004. Plant cytoplasm preserved by lightning. Tissue and Cell, 36:351-360. doi:10.1016/j.tice.2004.06.002

Wang, X. 2006. A chemical signal possibly related to physiology in fossil cells detected by energy dispersive X-ray microanalysis. Tissue and Cell, 38:43-51. doi:10.1016/j.tice.2005.10.003

Wang, X. 2007. High temperature as a mechanism for plant cytoplasm preservation in fossils. Acta Geologica Sinica, 81:183-193. doi:10.1111/j.1755-6724.2007.tb00943.x

Wang, X.; Du, K.; Yi, T. \& Jin, J. 2010. Cytoplasmic remains in an Eocene fossil stem. IAWA Journal, 31:363-367. doi:10.1163/22941932-90000029

Wang, X.; Liu, W.; Cui, J. \& Du, K. 2007. Palaeontological evidence for membrane fusion between a unit membrane and a halfunit membrane. Molecular Membrane Biology, 24:496-506. doi:10.1080/09687680701446973

Wang, X.; Yu, J. \& Fang, X. 2008. An AFM observation on fossil cytoplasm. Acta Geologica Sinica, 82:1141-1145. doi:10.1111/j.1755-6724.2008.tb00714.x

Received in 01 March, 2018; Accepted in 01 June, 2018. 